\title{
Chemical and biological indicators of soil quality in cultivation areas of the Cerrado
}

The present study aimed to evaluate the interference of the management adopted in Cerrado cultivation areas on the chemical and biological soil attributes. Fou soil management systems were studied (MC, NT3+SM, NT6+MB, and NT6+SMB), with different years of adoption and cover crops, and one area of native vegetation (NV). In each soil management system and in the NV, soil samples were collected at the depths of $0.0-0.05 \mathrm{~m}, 0.05-0.10 \mathrm{~m}$, and $0.10-0.20 \mathrm{~m}, 5$ replications. The effects of the treatments on the response variables were evaluated by ANOVA, and the means were compared by the Scott-Knott test at $5 \%$ of significance. Soil management with crop rotation and succession improved soil fertility since all chemical elements studied presented higher values when compared to the NV. The soil contents of organic carbon, macronutrients, microbial biomass carbon (Cmic), and soil basal respiration (SBR) were generally higher on the surface, with the lowest contents of Cmic being observed for the NT6+MB, and the NV presenting high SBR in all studied depths. The metabolic quotient was higher in depth. In general, our results revealed that the use of no-tillage systems, besides providing soil cover, also increases and maintains the chemical and biological attributes, respectively, thus improving soil quality.

Keywords: Conservation systems; Matopiba; Organic carbon.

\section{Indicadores químicos e biológicos de qualidade do solo em áreas de cultivo do Cerrado}

\begin{abstract}
O presente estudo teve como objetivo avaliar a influência do manejo adotado em áreas de cultivo no Cerrado sobre os atributos químicos e biológicos do solo. Foram estudados quatro sistemas de manejo do solo (MC, NT3+SM, NT6+MB e NT6+SMB), com diferentes anos de adoção e coberturas e uma área de vegetação nativa (NV). Em cada sistema de manejo do solo e na NV, as amostras de solo foram coletadas nas profundidades de 0,0-0,05m, 0,05-0,10m e 0,10-0,20m, com 5 repetições. Os efeitos dos tratamentos nas variáveis de resposta foram avaliados por ANOVA e as médias comparadas pelo teste de Scott-Knott a $5 \%$ de significância. O manejo do solo com rotação e sucessão de culturas melhorou a fertilidade do solo, uma vez que todos os elementos químicos estudados apresentaram valores superiores quando comparados ao NV. Os teores de carbono orgânico(SOC), macronutrientes, carbono da biomassa microbiana (Cmic) e respiração basal do solo (SBR) no solo foram geralmente maiores na superfície, com os menores teores de Cmic sendo observados para o NT6 + MB, e o NV apresentando alto SBR em todas as profundidades estudadas. O quociente metabólico foi maior em profundidade. De maneira geral, nossos resultados revelaram que o uso do sistema de plantio direto, além de proporcionar cobertura do solo, também aumenta e mantém os atributos químicos e biológicos, respectivamente, melhorando a qualidade do solo.
\end{abstract}

Palavras-chave: Sistemas de conservação; Matopiba; Carbono orgânico.

Topic: Ciências do Solo

Reviewed anonymously in the process of blind peer
Received: 08/06/2021

Approved: 24/06/2021
Patricia Carvalho da Silva (iD)

Universidade de Brasília, Brasil

http://lattes.cnpq.br/8695500137086031

http://orcid.org/0000-0003-4608-6164

patriciacarvalhoagro@gmail.com

Wesley dos Santos Souza (iD)

Universidade Federal Rural do Rio de Janeiro, Brasil

http://lattes.cnpq.br/4286185972062563

http://orcid.org/0000-0002-5186-6627

agrowesley95@gmail.com

Jenilton Gomes da Cunha (iD)

Universidade Federal do Piauí, Brasil

http://lattes.cnpq.br/2273843380199883

http://orcid.org/0000-0003-4110-6605

jeniltongomes@hotmail.com

\author{
Ericka Paloma Viana Maia (iD \\ Universidade Federal do Ceará, Brasil \\ http://lattes.cnpq.br/4692610262622259 \\ http://orcid.org/0000-0002-6026-5196 \\ erickapaloma.agronomia@gmail.com \\ Manoel Ribeiro Holanda Neto \\ Universidade Estadual do Piauí, Brasil \\ http://lattes.cnpq.br/8635138819949923 \\ http://orcid.org/0000-0003-1023-9763 \\ mrholandaneto@hotmail.com
}

Referencing this:

SILVA, P. C.; SOUZA, W. S.; CUNHA, J. G.; MAIA, E. P. V.; HOLANDA NETO, M. R.. Chemical and biological indicators of soil quality in cultivation areas of the Cerrado. Revista Ibero Americana de Ciências Ambientais, v.12, n.6, p.60-73, 2021. DOI:

http://doi.org/10.6008/CBPC2179-6858.2021.006.0005 


\section{INTRODUCTION}

The world demand for food has increased throughout the years, and estimations of the United Nations (UN, 2019) indicate that, until 2050, the world demand may increase by $70 \%$ due to populational growth, which in this century is estimated to reach 9.7 billion people. However, this increase will only be sustainable if, for such, agriculture does not trespass the expansion of cultivation areas beyond the $20 \%$ considered sustainable (MUTEIA, 2015). In view of this, the challenge of the agricultural sector is to ensure the expansion of crops with the increase in yield and, at the same time, to incorporate the conservationist agenda, ensuring the availability of natural capital and climatic safety for the sustainability of agricultural production (BUSTAMANTE et al., 2014).

Most of the Brazilian agricultural systems are located in the Cerrado biome region. The agricultural area in this region expanded and approximately $70 \%$ of this increase occurred in areas with degraded pastures (CARNEIRO FILHO et al., 2016). The Cerrado of western Bahia is located in the region considered the last agricultural frontier in Brazil (MATOPIBA), a region with great potential for grain production and has been growing in recent years.

The anthropogenic land use promotes changes in soil carbon storage due to alterations in the quality and quantity of organic matter, affecting the physical and chemical properties of the soils, and directly impacting on microorganisms and microbial processes. As a result, nutrient cycling and availability are affected, and the sustainability of this ecosystem is disturbed (GARCÍA-ORENES et al., 2013). However, problems can be minimized by the use of sustainable agricultural systems and soil use practices that favor interactions and recover and/or increase the fertility and microbiota of the soil (DIAS et al., 2019).

Soil management with no-tillage farming is an alternative that can contribute to soil quality (SHIWAKOTI et al., 2019; SOARES et al., 2020). In Brazil, millions of hectares are cultivated in no-tillage farming with a wide diversity of crops, integrated crop-livestock-forest systems (SANT'ANNA et al., 2017), crops intercropped with grasses or legumes (ENSINAS et al., 2016), and cover plants during the off-season (CARVALHO et al., 2012). However, depending on the time of adoption of the no-tillage farming system and the crop rotation used, soil quality may be affected and even depreciated (SOARES et al., 2020).

The monitoring of soil quality consists of evaluating its physical, chemical, biological, and biochemical properties, which vary as a function of the managements applied. Therefore, such properties indicate changes in soil quality under different management system (BABUJIA et al., 2010; TANG et al., 2020). In view of the significant importance of the chemical and biological attributes on soil quality, for allowing a better structuration and a richer chemical composition through nutrient cycling, this study aimed to evaluate the interference of soil management and the time of adoption of the no-tillage farming system, in Cerrado cultivation areas, on the biological and chemical attributes of the soil, aiming at clarifying the sustainability of the systems in these areas. 


\section{MATERIALS AND METHODS}

\section{Characterization of the Area and Experimental Design}

The study was developed in the NSa Aparecida Farm, in areas of grain producers belonging to the COACERAL cooperative, municipality of Formosa do Rio Preto - BA, MATOPIBA region. The soils of the areas are classified as typic Dystrophic Red Latosol in the Brazilian Soil Classification System (SANTOS et al., 2018), with a sandy-clay loam texture. The climate of the region is tropical, with a dry winter season and a rainy summer season, classified as Aw type in the Köppen system, with a mean temperature of 26.5 으, annual rainfall of $1,100 \mathrm{~mm}$, and a rainy season concentrated in the months from November to March.

The experimental design was in randomized blocks, with subdivided plots and five replications: the main plot was composed of the soil management systems, and the subplots consisted of the depths. The studied systems were: 1- Minimum cultivation with soybean-millet rotation, one year of adoption (MC); 2No-tillage system, three years of adoption, with soybean/millet rotation and brachiaria as a cover crop (NT3+SM); 3- No-tillage system, six years of adoption, with soybean/brachiaria cultivation and brachiaria as a cover crop for five years and maize/brachiaria rotation in the last year (NT6+MB); 4- No-tillage system, six years of adoption, with soybean/brachiaria/maize/brachiaria rotation and soybean cultivation intercropped with Brachiaria (NT6+SBM), besides one area under native vegetation (NV), as the reference for a balanced environment.

The soil samples were collected in October 2015, from each soil management system and from the reference area (native vegetation), at the depths of $0.0-0.05,0.05-0.10$, and $0.10-0.20 \mathrm{~m}$. The samples for microbiological analyses were preserved in a cold room at \pm 4 으, where they remained for two months until the conclusion of the analyses. The samples for the chemical attributes were processed and kept at ambient temperature, for the same storage period.

\section{Chemical Variables}

The $\mathrm{pH}$ was determined in water $(1: 2.5)$ by potentiometry. The exchangeable acidity $\left(\mathrm{Al}^{+3}\right)$ was extracted with $\mathrm{KCL}_{1} \mathrm{~mol} \mathrm{~L}^{-1}$ and quantified by titration with sodium hydroxide $0.025 \mathrm{~mol} \mathrm{~L}^{-1}$. The potential acidity $\left(\mathrm{H}+\mathrm{Al}^{3+}\right)$ was extracted with calcium acetate $0.5 \mathrm{~mol} \mathrm{L^{-1 }}$. Phosphorus and potassium were extracted with Mehlich 1 and determined by colorimetry and flame photometry, respectively. Calcium and magnesium were extracted with $\mathrm{KCl} 1 \mathrm{~mol} \mathrm{~L}^{-1}$ and determined by titration (TEXEIRA et al., 2017). The sum of bases (SB) was obtained by the expression: $\mathrm{SB}=\mathrm{Ca}^{2+}+\mathrm{Mg}^{2+}+\mathrm{K}^{+}(\mathrm{cmolc} \mathrm{dm}-3)$. The cation exchange capacity (CEC) was determined by the expression: $\mathrm{CEC}=\mathrm{Ca}^{+2}+\mathrm{Mg}^{+2}+\mathrm{K}^{+}+\mathrm{H}^{+}+\mathrm{Al}^{+3}\left(\mathrm{cmolc} \mathrm{dm}^{-3}\right)$. Base saturation (V\%) was obtained

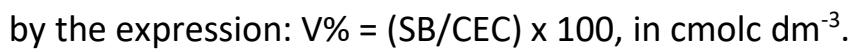

\section{Microbiological Variables}

The microbial biomass carbon ( $\mathrm{Cmic}$ ) was determined by the irradiation and extraction method, using a microwave oven (ISLAM et al., 1998), and quantified by wet oxidation (YEOMANS et al., 1988). Soil basal 
respiration (SBR) was obtained by the method of sample incubation in $\mathrm{NaOH}$, with $\mathrm{CO}_{2}$ capture, for 7 days, through the adaptation of the fumigation-incubation method proposed by Jenkinson et al. (1976). The soil organic carbon $(\mathrm{SOC})$ was determined by wet oxidation of organic matter with potassium dichromate in sulfuric medium, employing as an energy source the heat released by the $\mathrm{H}_{2} \mathrm{SO}_{4}$; the excess of dichromate, after the oxidation, was titrated with a solution of ferrous ammonium sulfate (YEOMANS et al., 1988). The metabolic quotient $\left(\mathrm{qCO}_{2}\right)$ was calculated by the ratio between basal respiration and microbial biomass carbon (MUNIZ et al., 2018).

\section{Statistical Analysis}

The data were subjected to the tests of normality of residuals and homogeneity of variances. Afterward, the analysis of variance was performed by the F-test, and, based on the significance, the comparison of means was performed by the Scott-Knott test, using the Sisvar statistical software. The chemical and biological data were subjected to Pearson's linear correlation. All statistical analyses were performed by considering a $5 \%$ level of probability $(p \leq 0.05)$.

\section{RESULTS AND DISCUSSION}

In the present study it is observed that, for all variables, there was a highly significant additive influence of the factors Management Systems (MS) and Layers (L), as well as a joint contribution of the interaction between both factors ( $\mathrm{MS} \times \mathrm{L}$ ), except for the $\mathrm{SOC}$ and $\mathrm{qCO}_{2}$, influenced only by the layers factor (Table 1).

Table 1: Summary of the analysis of variance for the chemical and biological soil variables under different use and management systems, in different layers.

\begin{tabular}{|c|c|c|c|c|c|c|c|}
\hline \multicolumn{8}{|l|}{ Value 'F' } \\
\hline Sources of Variation & $\mathrm{pH}$ & $\mathrm{Al}^{3+}$ & $\mathrm{H}+\mathrm{Al}^{3+}$ & $\mathrm{K}^{+}$ & $\mathrm{P}$ & $\mathrm{Ca}^{2+}$ & $\mathrm{Mg}^{2+}$ \\
\hline Management systems (MS) & $18.04 * *$ & $98.39 * *$ & $14.08 * *$ & $61.11 * *$ & $113.09 * *$ & $117.96 * *$ & $11.36 * *$ \\
\hline Layers $(\mathrm{L})$ & $44.67^{* *}$ & $108.36^{* *}$ & $19.25^{* *}$ & $10.45^{* *}$ & $152.75^{* *}$ & $71.84^{* *}$ & $43.32 * *$ \\
\hline$M \times L$ & $4.98^{* *}$ & $21.78^{* *}$ & $10.78^{* *}$ & $47.24 * *$ & $17.32 * *$ & $5.17^{* *}$ & $8.15^{* *}$ \\
\hline CV\% (MS) & 4.47 & 16.90 & 14.89 & 23.29 & 27.10 & 17.85 & 31.96 \\
\hline CV\% (L) & 5.86 & 19.94 & 12.74 & 14.23 & 20.61 & 25.38 & 23.84 \\
\hline Sources of Variation & SB & CEC & $\mathrm{V}$ & SOC & Cmic & SBR & $\mathrm{qCO}_{2}$ \\
\hline Management systems (MS) & $113.45^{* *}$ & $19.17^{* *}$ & $60.30 * *$ & $1.44^{\mathrm{ns}}$ & $4.87 * *$ & $24.52 * *$ & $1.03^{\text {ns }}$ \\
\hline Layers (L) & $264.53^{* *}$ & $28.45^{* *}$ & $107.12^{* *}$ & $51.08 * *$ & $13.83^{* *}$ & $15.86^{* *}$ & $3.24^{*}$ \\
\hline$M \times L$ & $13.61^{* *}$ & $4.58^{* *}$ & $9.87^{* *}$ & $1.15^{\mathrm{ns}}$ & $2.33^{*}$ & $8.97 * *$ & $0.81^{\text {ns }}$ \\
\hline $\mathrm{CV} \%$ (MS) & 14.21 & 9.81 & 18.04 & 21.86 & 42.48 & 16.10 & 75.38 \\
\hline CV\% (L) & 11.39 & 7.26 & 16.07 & 16.14 & 44.54 & 14.65 & 78.57 \\
\hline
\end{tabular}

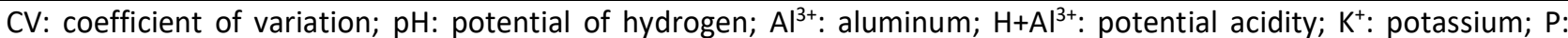
phosphorus; $\mathrm{Ca}^{2+}$ : calcium; $\mathrm{Mg}^{2+}$ : magnesium; $\mathrm{SB}$ : sum of bases; $\mathrm{SBR}$ : soil basal respiration; $\mathrm{qCO}_{2}$ : metabolic quotient; ns: not significant; ${ }^{*}$ and ${ }^{* *}$ : significant at $5 \%(p \leq 0.05)$ and $1 \%(p \leq 0.01)$ of probability, respectively, by the Scott Knott test.

\section{Chemical attributes}

The contents of $\mathrm{Al}^{3+}$ and $\mathrm{H}+\mathrm{Al}{ }^{3+}$ (Figures $1 \mathrm{~B}-\mathrm{C}$ ) were higher in the native vegetation, at the surface $(0.05-0.10 \mathrm{~m})$, and in systems in depth $(0.10-0.20 \mathrm{~m})$; however, the minimum cultivation (MC) presented superior $\mathrm{H}+\mathrm{Al}^{3+}$ values compared to those verified in the remaining systems. These results justify the $\mathrm{pH}$ 
increase at the $0.0-0.05 \mathrm{~m}$ depth in the MC, NT3+SM, and NT6+SMB systems, with higher soil acidity in deeper layers of the systems and on the surface of the NV area (Figure 1A). The results observed in the NV area are predominant characteristics of Cerrado soils, most of which present an advanced degree of weathering, with high acidity, low natural fertility, and low reactivity clays (SANTOS et al., 2018).

A.

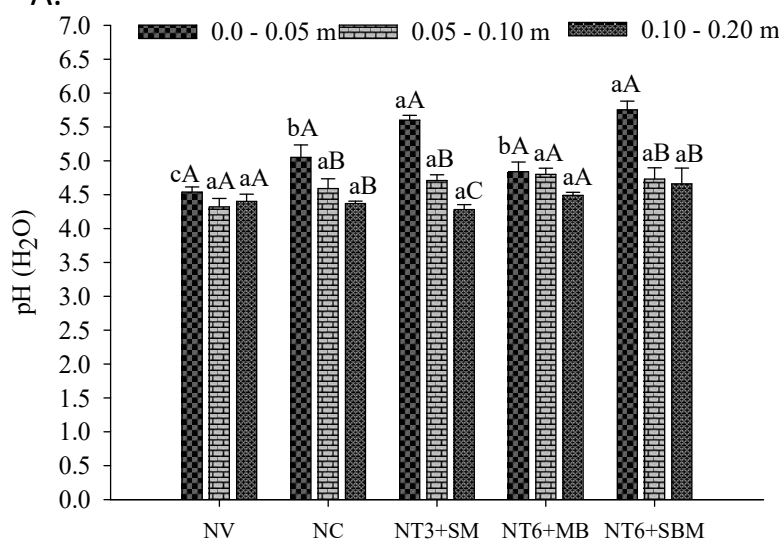

C.

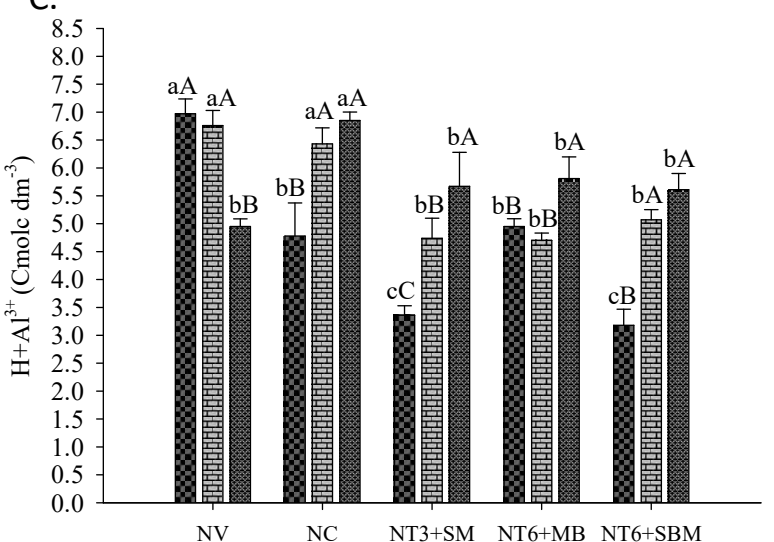

E.

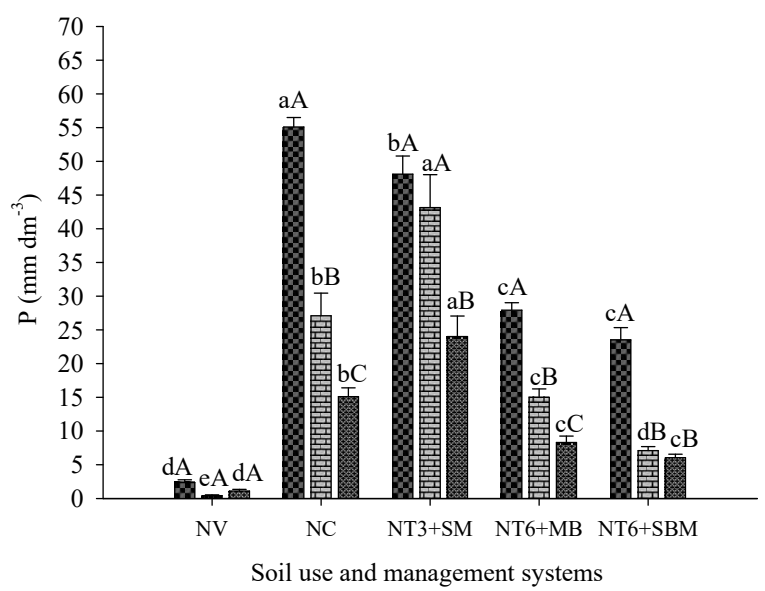

B.

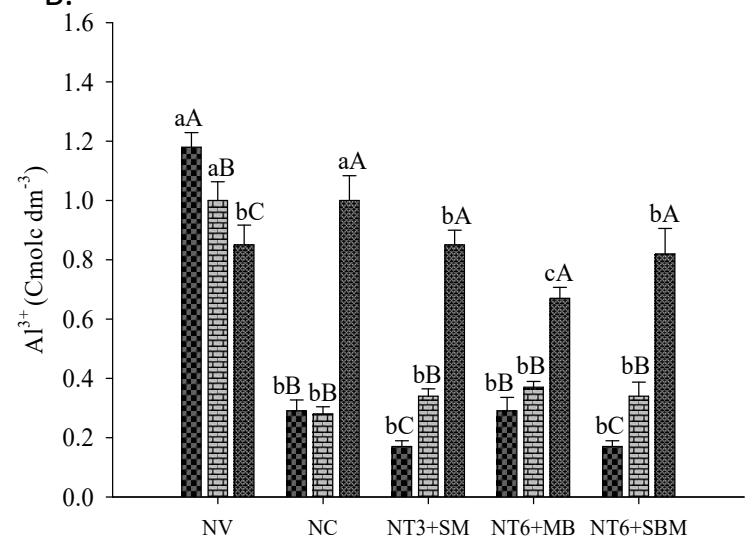

D.

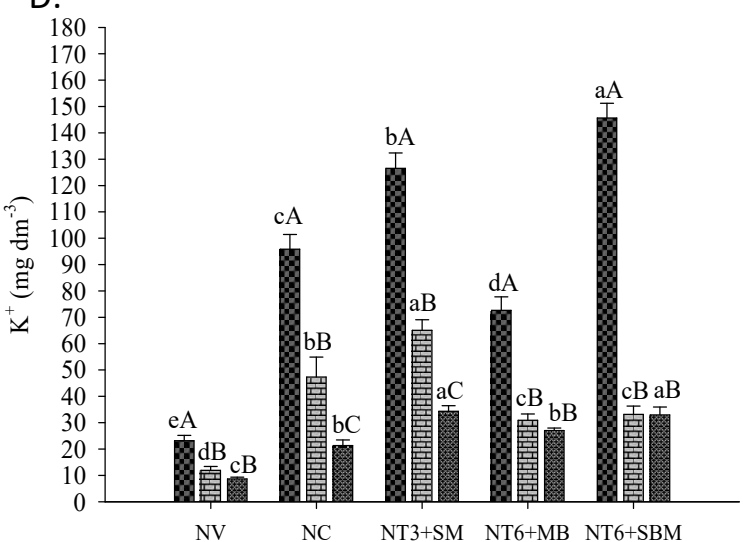

F.

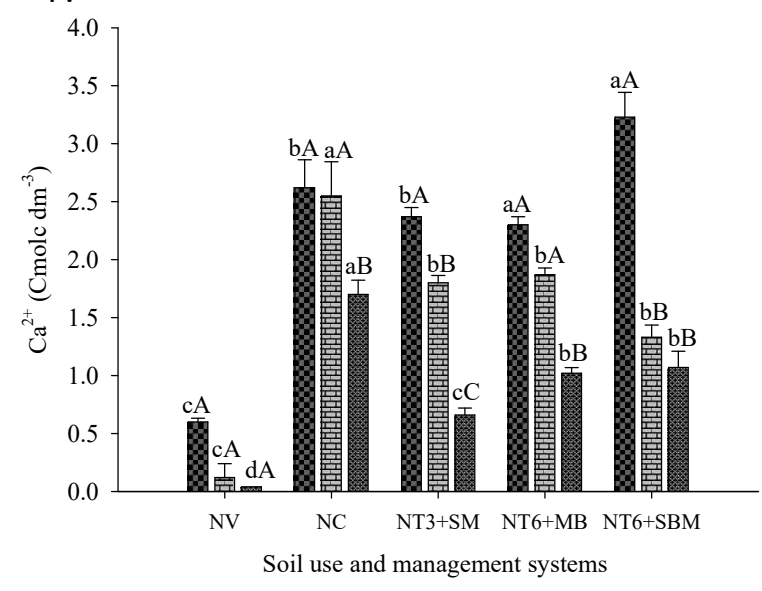

Figure 1: Influence of different soil use and management systems and layers on the potential of hydrogen $(\mathrm{pH}-\mathrm{A})$ and contents of aluminum $\left.(A)^{3+}-B\right)$, potential acidity $\left.(H+A)^{3+}-C\right)$, potassium $\left(K^{+}-D\right)$, phosphorus $(P-E)$ and calcium $\left(\mathrm{Ca}^{2+}-\right.$ F). Lowercase letters compare layers, individually, as a function of the soil use and management systems. Uppercase letters compare layers within each soil use and management system, in isolation. Same letters do not differ from each other by the Scott-Knott test at $5 \%$ of probability.

The increase in the $\mathrm{pH}$ and the reduction in the contents of $\mathrm{Al}^{3+}$ and $\mathrm{H}+\mathrm{Al}^{3+}$ in the management 
systems occur due to the application of limestone, which provides an increase in the concentration of hydroxyls $\left(\mathrm{OH}^{-}\right)$, calcium, and magnesium in the soil solution, contributing to the precipitation and neutralization of toxic ions, such as exchangeable $\mathrm{Al}^{3+}$, especially in the more superficial layers, due to the minimum soil turning (MOREIRA et al., 2015). Another factor that can contribute to this result is the accumulation of organic matter, which has the ability to complex $\mathrm{Al}^{3+}$ ions, reducing its toxicity and availability in the soil solution (BALDOTTO et al., 2015).

The lowest contents of macronutrients were found in the NV area, at all depths studied (Figure 1 and 2 ), which can be justified by the high degree of soil weathering in this area, such as occurs in most of the Cerrado areas (LEITE et al., 2010). The highest values for $\mathrm{K}^{+}, \mathrm{P}, \mathrm{Ca}^{2+}$, and $\mathrm{Mg}^{2+}$ found in the conservationist management systems are explained by the alterations in the natural conditions of soil fertility due to the adoption of the practices of liming, base fertilization, and nutritional maintenance and/or reposition throughout the years of adoption of the systems, promoting the addition of nutrients to the soil (Figure 1DF and $2 A)$.

Since, in the systems, the soil cover consists of maize and brachiaria straw, which feature a high $\mathrm{C} / \mathrm{N}$ ratio, important nutrient reserves for the soil are obtained through this soil cover, whose availability may be either rapid and intense or slow and gradual, according to the interaction with the climatic factors, such as rainfall and temperature, associated with the activity of macro and microbiological soil organisms. Pariz et al. (2011), studying the decomposition of forage grass straw fertilized with nitrogen, verified that the straw of $U$. brizantha $\mathrm{cv}$. Marandu provided a greater release in the contents of $\mathrm{P}$ and $\mathrm{K}^{+}$at the soil surface. These authors also highlighted the use potential of these grasses as cover crops in conservationist systems. In studies performed by Mendonça et al. (2015), evaluating the nutrient release from forage straw, the authors highlighted that $\mathrm{Ca}^{2+}$ was extracted in lower amounts in relation to $\mathrm{K}^{+}$, thus allowing to deduce that calcium was intensely released from the straw, thus favoring the successive crop.

Significant differences in the contents of $\mathrm{K}^{+}$were observed in the areas with different years of adoption of the no-tillage system and among soil depths, with higher values at the surface of the NT6+SMB and NT3+SM (Figure 1D) systems. The increase of $\mathrm{K}^{+}$at the surface may be related to the superficial application of potassium fertilizers and the predominance of plant residues from cover plants in the superficial layers, thus avoiding that most of these nutrients are distributed in the arable soil layer and then leached. Likewise, Leal et al. (2008) verified a potassium accumulation at the superficial layers of Cerrado soils managed in a no-tillage system for three years, with annual potassium application. These authors attributed this fact to a probable extraction of $\mathrm{K}^{+}$from the deeper layers by the roots of the soybean plants and cover crops (Sorghum and Eleusine coracana).

Furthermore, the species used in crop rotation also influence the contents of $\mathrm{K}^{+}$in the soil since the amount of nutrients exported by the plant at harvest differs with each crop. The soybean crop, exhibits greater potassium removal at grain harvest since the harvested part of the crop (grains) presents higher $\mathrm{K}^{+}$ concentrations and higher yield, already maize have higher allocation for potassium in straw that soybean (FAGERIA, 2004; RAZA et al., 2019). Therefore, the maize crop provides more nutrients through the plant 
residues that remain on the soil, and there is less nutrient loss in the system through its grain harvest. In this manner, the higher contents of $\mathrm{K}^{+}$on the surface of the NT6+SMB and NT3+SM may be a consequence of the existence of soybean/maize crop rotation, unlike what happened in the NT6-MB, with lower contents of $\mathrm{K}^{+}$, in which maize cultivation occurred only in the last year.

The contents of $\mathrm{P}$ were higher in the systems with a lower time of consolidation, in $\mathrm{MC}$ at the superficial layer, and in the NT3+SM in depth (Figure 1E). $\mathrm{Ca}^{2+}$ and $\mathrm{Mg}^{2+}$ presented distinct distributions throughout the soil profile, varying according to the system employed (Figure $1 \mathrm{~F}$ and $2 \mathrm{~A}$ ). The contents of $\mathrm{Ca}^{2+}$ in the six years systems were higher at the surface; however, in depth, the highest contents were found in the $\mathrm{MC} . \mathrm{Mg}^{2+}$ was higher at the surface in soils under $\mathrm{MC}$ and $\mathrm{NT3+SM}$, and in depth in the already consolidated systems (NT3+SM, NT6+MBS, and NT6+SMB). The reduction of $\mathrm{Ca}^{2+}$ and $\mathrm{Mg}^{2+}$ in deeper layers is associated with the application of limestone at the surface, which reduces the efficiency of acidity correction in depth due to the low mobility of the limestone. According to Leite et al. (2010), it is common to observe higher contents of this nutrient at the surface soil layer due to the application of correctives, without incorporation, thus reducing the contact surface between soil and corrective, delaying the effects of liming and restricting the reaction to the superficial centimeters of the soil.

A.
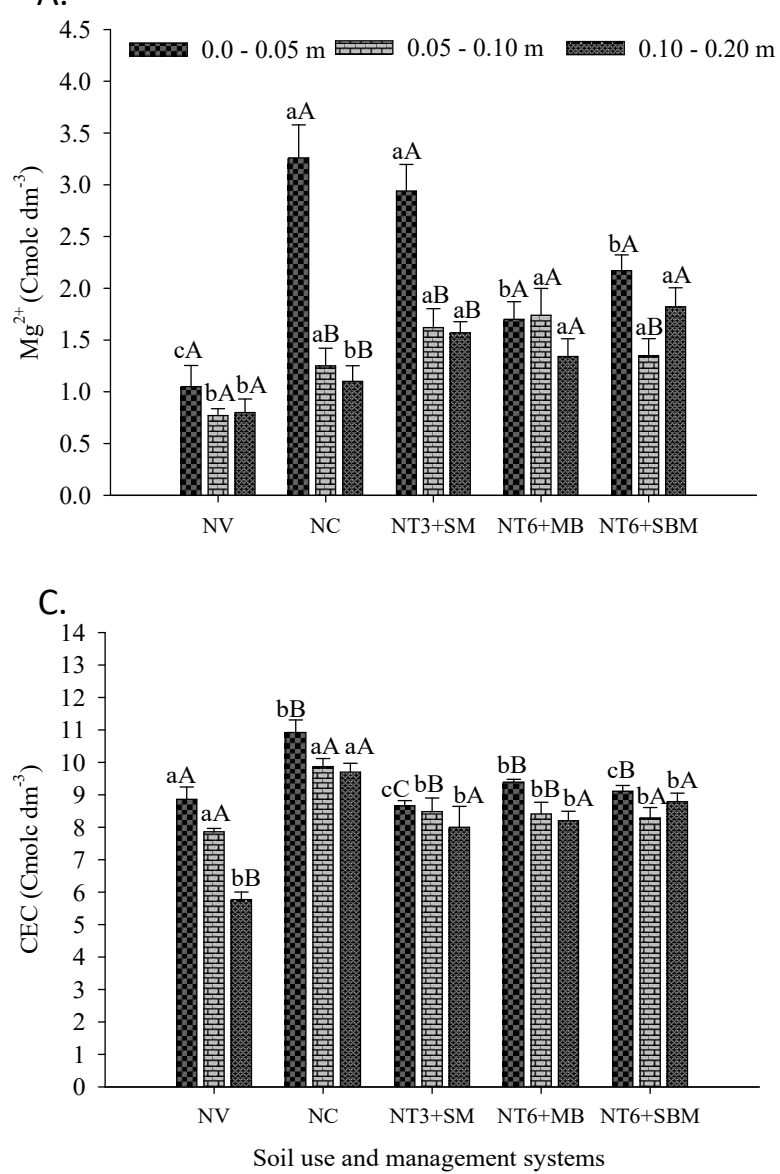

B.
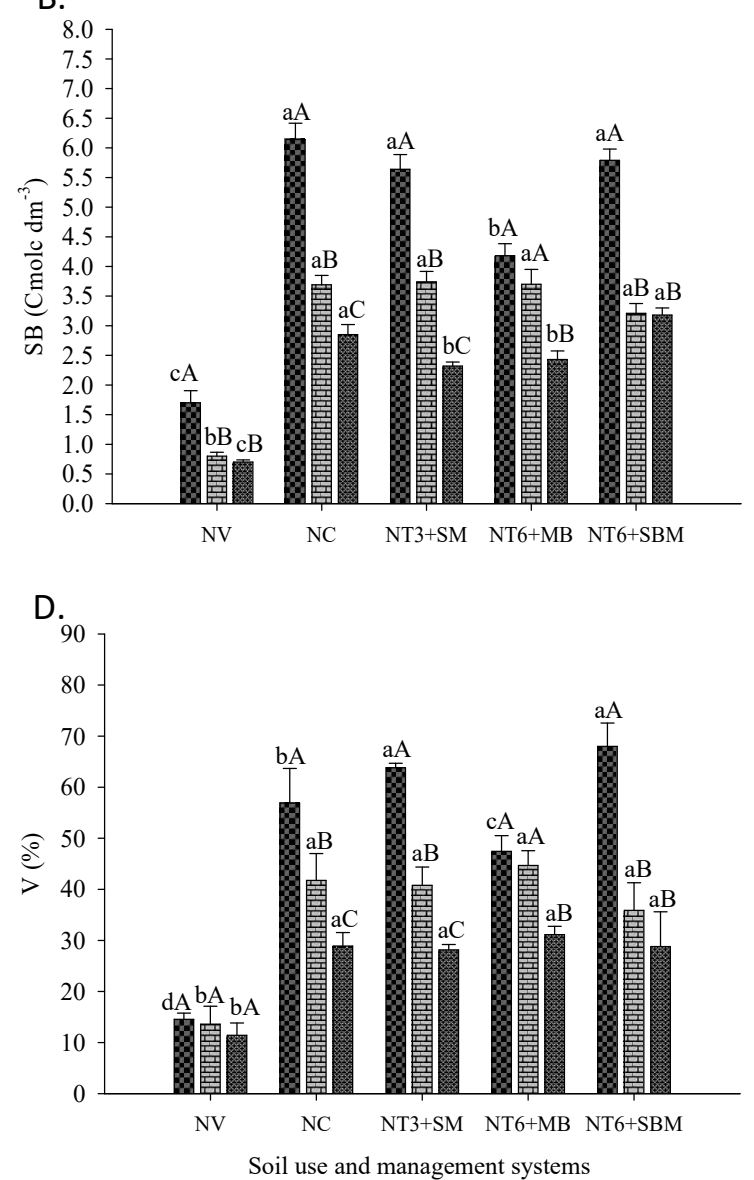

Figure 2: Influence of different soil use and management systems and layers on the contents of magnesium $\left(\mathrm{Mg}^{2+}-\mathrm{A}\right)$, sum of bases (SB - B), cation exchange capacity (CEC - C), and base saturation (V - D). Lowercase letters compare layers, individually, as a function of the soil use and management systems. Uppercase letters compare layers within each soil use and management system, in isolation. Same letters do not differ from each other by the Scott-Knott test at $5 \%$ of probability. 
Furthermore, the higher contents of $\mathrm{Mg}^{2+}$ at the surface, in the systems, may be attributed to the capacity of this element in being easily released from the straw to the soil via decomposition, considering that the initial release of $\mathrm{Mg}^{2+}$, in great amounts, occurs because $70 \%$ of this element is located in the plant vacuole, thus allowing part of the magnesium to be rapidly released since this portion is not part of the cell constituents (MARSCHNER, 1995). The remainder (30\%) of $\mathrm{Mg}^{2+}$ is afterward released in a gradual manner since it is part of the structural compounds of plants (MENDONÇA et al., 2015).

In general, the values of SB, CEC, and V\% obtained a statistical difference between the systems, and these were superior to the NV area (Figure 2B-D). There was also a difference between the depths, in which the most superficial layer ( 0 to $0.05 \mathrm{~m}$ ) differed, presenting higher values of $\mathrm{SB}, \mathrm{CEC}$, and V\%, which was already expected due to the higher concentration of bases at this depth. The results of V\% below $50 \%$ in the NV evidenced a dystrophic character of ow natural fertility in the Cerrado soil. As for the areas with no-tillage systems, except the NT6+MB, they presented a eutrophic character, with V\% above 50\%. Sousa et al. (2004) recommend that, for the Cerrado soils, the values of base saturation (V\%) should be equal to 50 and 60 for the soybean and maize crops, respectively.

\section{Biological attributes}

For the content of SOC, there was no interaction between systems and depths. The factors varied independently, and no significant difference was observed between the systems. The SOC was evaluated at the different depths, and a higher content was observed at the surface ( 0.0 to $0.05 \mathrm{~m})$, while a reduction was observed with the increase in depth (Figure 3C). These results are similar to those found by Costa et al. (2021) when studying carbon in Cerrado areas, under no-tillage farming, with different soil cover crops. The significant difference between soil depths may be related to the deposition of residues at the surface, without soil turning and consequent incorporation into the soil, which affects the decomposition rate of organic matter and, consequently, nutrient release, forming a surface concentration gradient of organic matter (ACQUA et al., 2013).

The absence of significant differences for the contents of SOC between the studied systems and the NV demonstrate that the time of cultivation was sufficient for the contents of SOC to level with those of the area with natural soil condition (NV). Areas with native vegetation, when replaced by areas of agricultural cultivation with conventional management, normally present a reduction of the organic carbon stock in the soil at the surface layers; however, depending on the management adopted, the carbon content may be increased or maintained at close levels due to the incorporation of vegetal residues by cover plants, as some authors observed the maintenance or even the increase of these stocks when under no-tillage farming (FRAZÃO et al., 2010; LEITE et al., 2010).

The change in the land use can promote positive impacts on soil carbon when the area is wellmanaged, and this may occur due to the absence of soil turning in these areas, which contributes to the preservation of soil aggregates (SANTOS et al., 2019); its location within the aggregate is a key factor to establish and storage soil organic carbon (VICENTE et al., 2019). According to the management adopted, 
carbon soil does not decrease when there is a conversion of the forest into a farming system, and the intensity of the changes in soil organic carbon shall depend on the type of land use adopted, which may be different for each soil layer (EZE et al., 2018), as observed in this study. The adoption of management practices that increase the $\mathrm{C}$ stock in the soil can provide a reduction in the anthropic emissions, the improvement in the ecosystem services and soil quality, the increase of agricultural yield, the promotion of global food security, and the improvement of soil resilience in order to adapt to extreme climatic events (LAL, 2011).

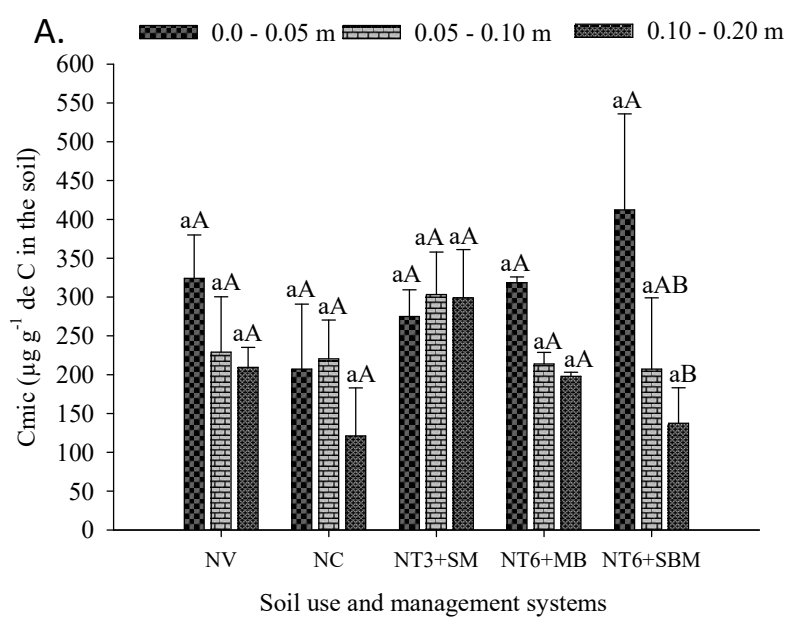

B.

C.
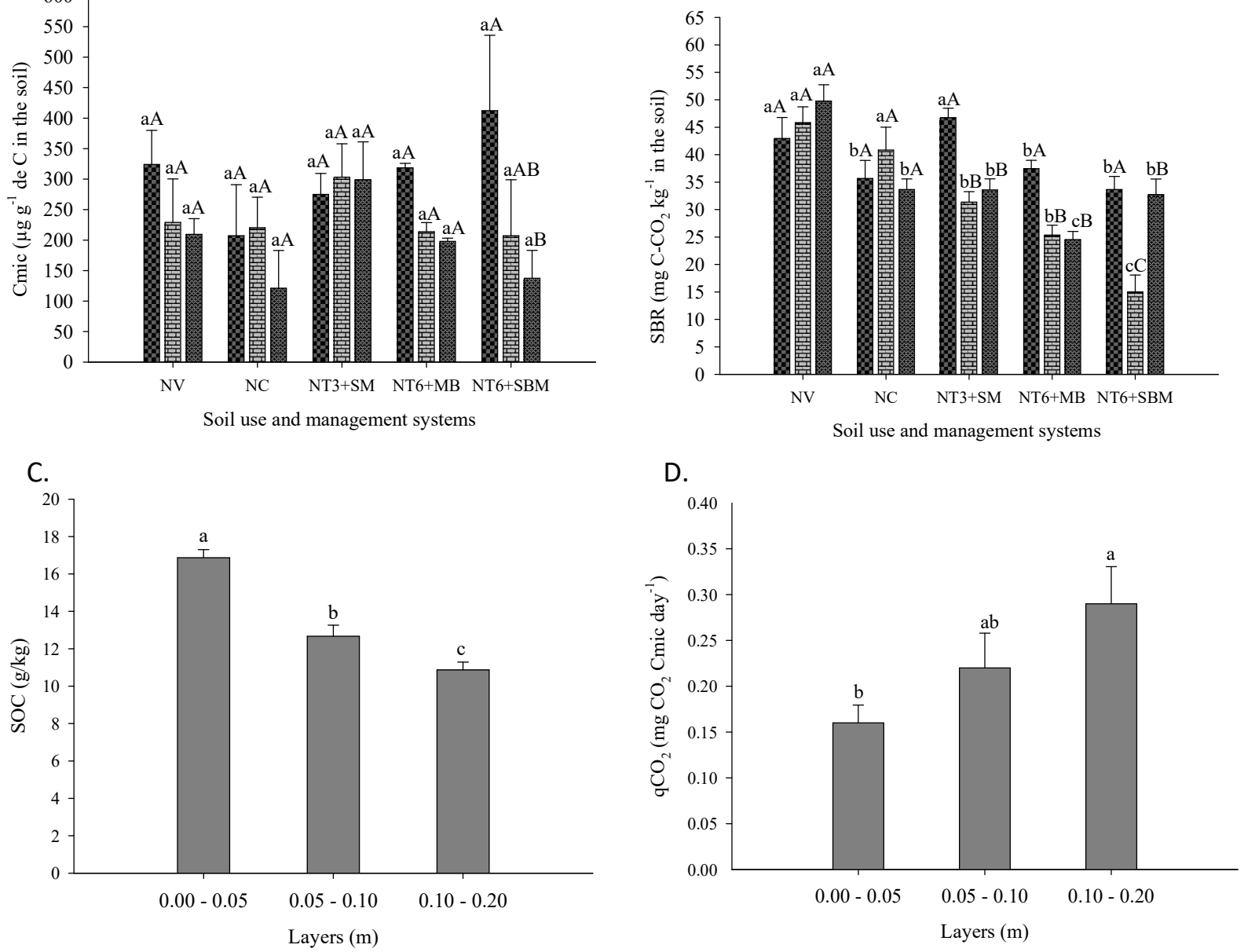

Figure 3: Influence of different soil use and management systems and layers on microbial carbon (Cmic - A), soil basal respiration (SBR - B); Influence of different soil layers on the soil organic carbon (SOC - C) and metabolic quotient $\left(q \mathrm{qO}_{2}-\mathrm{D}\right)$. Lowercase letters compare layers, individually, as a function of the soil use and management systems. Uppercase letters compare layers within each soil use and management system, in isolation. Same letters do not differ from each other by the Scott-Knott test at $5 \%$ of probability.

In a general manner, the lowest contents of $C_{\text {mic }}$ were observed in the NT6+MB, at all depths studied. The highest content of carbon present in the microbial biomass was observed in treatments NV, MC, and NT6+SMB, at the surface $(0.0-0.05 \mathrm{~m}$ ) (Figure $3 \mathrm{~A})$. This increase of the $\mathrm{Cmic}$ at the surface may have occurred due to the greater presence of roots and organic matter, which are considered the main sources of energy for the microbial biomass. Furthermore, the abundant root system of the grasses promotes a greater release of exudates and contributes to the increase of the population of microorganisms in the rhizosphere. The permanent maintenance of soil cover and the absence of disturbs caused by agricultural practices contribute to the appearance of favorable conditions to microbial growth in pasture areas of the Cerrado (MUNIZ et al., 
2011).

The SBR was higher at the surface in treatments NT3+SM, NT6+MB, and NT6+SMB, with a significant reduction with the increase in depth. The NV presented high SBR at all depths studied (Figure 3B). Oliveira et al. (2016) verified greater basal respiration in native Cerrado areas compared to integrated production systems and continuous pasture. This greater $\mathrm{CO}_{2}$ release expressed by the SBR in the soil with native vegetation may occur as a function of the constant residue incorporation with the accumulation of organic matter in labile fractions, promoting the increase of microbial biomass (Figure $3 \mathrm{~A}$ ) and biological activity on this material, resulting in the release of $\mathrm{CO}_{2}$ (KUZYAKOV, 2010).

The $\mathrm{MC}$ and $\mathrm{NT3}+\mathrm{SM}$ presented high $\mathrm{CO}_{2}$ release at the $0.05-0.10 \mathrm{~m}$ and $0.0-0.05 \mathrm{~m}$ depths, respectively. The lowest values of basal respiration were found in the no-tillage farming areas, in the NT6+MB and NT6+SMB, at all depths, and in the NT3+SM, in depth (Figure 3B), indicating that the management of the soil did not favor the emission of $\mathrm{CO}_{2}$ to the atmosphere. These data demonstrate the relevance of adopting management systems that prioritize the absence of soil turning, as well as crop rotation and succession, and the maintenance of soil cover by plant residues since a lower SBR and a higher content of $\mathrm{C}_{\text {mic }}$ evidence that these systems may be working as a carbon drain. According to Santana et al. (2017), a more efficient microbial biomass would be that in which a lower amount of carbon is lost as $\mathrm{CO}_{2}$ by respiration, and a significant carbon fraction would be incorporated into the microbial biomass.

The $\mathrm{qCO}_{2}$ is expressed in the amount of $\mathrm{CO}_{2}$ released by the amount of carbon in the biomass as a function of time, representing the specific respiration rate of the microbial biomass (ALVES et al., 2011). For the content of $\mathrm{qCO}_{2}$, there was no interaction between systems and depths. The factors varied independently, and no significant difference was observed between the systems (Figure 3D). The increase in the $\mathrm{qCO}_{2}$, observed at greater depths, indicates that the microbial biomass would be acting in the decomposition of soil organic matter. High values of $\mathrm{C}_{\text {mic }}$ and reduction of the $q \mathrm{CO}_{2}$, as it occurs at the depth from 0.0 to $0.05 \mathrm{~m}$, indicate that the microbial biomass is being more efficient, that is, there is lower $\mathrm{CO}_{2}$ loss per unit of biomass. This may be explained by the fact that when the microbial biomass becomes more efficient, less $\mathrm{CO}_{2}$ is lost by respiration, and a higher $\mathrm{C}$ proportion is incorporated into the microbial tissues, resulting in the decrease of the $\mathrm{qCO}_{2}$ (SILVA et al., 2007).

The indicator variables of soil acidity $\left(\mathrm{Al}^{3+}\right.$ and $\left.\mathrm{H}+\mathrm{Al}^{3+}\right)$ correlated negatively with the $\mathrm{pH}$, macronutrients, $\mathrm{SB}$, and $\mathrm{V} \%$ since, as the $\mathrm{pH}$ increases, the soil becomes less acid, reducing the availability of these elements and increasing the availability of macronutrients, resulting in higher SB and V\% values (Table 2). The increase in the $\mathrm{pH}$ and the reduction in the contents of $\mathrm{Al}^{3+}$ and $\mathrm{H}+\mathrm{Al}^{3+}$ in the management systems occur because the application of limestone provides an increase in the concentration of hydroxyls $\left(\mathrm{OH}^{-}\right)$, calcium, and magnesium in the soil solution, which contributes to the precipitation and neutralization of toxic ions, such as exchangeable $\mathrm{Al}^{3+}$, especially in the more superficial layers, due to the minimum soil turning (MOREIRA et al., 2015). 
Table 2: Pearson's linear correlation of the chemical and microbiological attributes of a soil under different use and management systems, in different layers.

\begin{tabular}{|c|c|c|c|c|c|c|c|c|c|c|c|c|c|c|}
\hline & $\mathrm{pH}$ & $\mathrm{H}+\mathrm{Al}^{3+}$ & $\mathrm{Al}^{3+}$ & $\mathrm{Ca}^{2+}$ & $\mathrm{Mg}^{2+}$ & $\mathrm{P}$ & $\mathrm{K}^{+}$ & SB & CEC & V\% & SBR & $\mathrm{C}_{\text {mic }}$ & $\mathrm{qCO}_{2}$ & $\mathrm{SOC}$ \\
\hline $\mathrm{pH}$ & 1 & & & & & & & & & & & & & \\
\hline $\mathrm{H}+\mathrm{Al}^{3+}$ & $-0.73^{* *}$ & 1 & & & & & & & & & & & & \\
\hline $\mathrm{Al}^{3+}$ & $-0.65^{* *}$ & $0.65^{* *}$ & 1 & & & & & & & & & & & \\
\hline $\mathrm{Ca}^{2+}$ & $0.67^{* *}$ & $-0.51^{* *}$ & $-0.77^{* *}$ & 1 & & & & & & & & & & \\
\hline $\mathrm{Mg}^{2+}$ & $0.62^{* *}$ & $-0.52^{* *}$ & $-0.59^{* *}$ & $0.55^{* *}$ & 1 & & & & & & & & & \\
\hline $\mathrm{P}$ & $0.46^{* *}$ & $-0.44^{* *}$ & $-0.67^{* *}$ & $0.65^{* *}$ & $0.71^{* *}$ & 1 & & & & & & & & \\
\hline $\mathrm{K}^{+}$ & $0.79^{* *}$ & $-0.65^{* *}$ & $-0.71^{* *}$ & $0.75^{* *}$ & $0.70^{* *}$ & $0.70^{* *}$ & 1 & & & & & & & \\
\hline SB & $0.74^{* *}$ & $-0.60^{* *}$ & $-0.79^{* *}$ & $0.89^{* *}$ & $0.84^{* *}$ & $0.77^{* *}$ & $0.86^{* *}$ & 1 & & & & & & \\
\hline CEC & $0.20^{\mathrm{ns}}$ & $0.23^{\text {ns }}$ & $-0.31^{\mathrm{ns}}$ & $0.58^{* *}$ & $0.49^{* *}$ & $0.49^{* *}$ & $0.42^{* *}$ & $0.62^{* *}$ & 1 & & & & & \\
\hline V\% & $0.84^{\text {ns }}$ & $-0.73^{* *}$ & $-0.78^{* *}$ & $0.82^{\text {ns }}$ & $0.73^{* *}$ & $0.61^{* *}$ & $0.80^{* *}$ & $0.88^{* *}$ & $0.35^{\mathrm{ns}}$ & 1 & & & & \\
\hline SBR & $0.08^{\text {ns }}$ & $0.02^{\text {ns }}$ & $0.18^{\mathrm{ns}}$ & $-0.11^{\text {ns }}$ & $-0.07^{n s}$ & $0.04^{\text {ns }}$ & $0.08^{\text {ns }}$ & $-0.12^{\text {ns }}$ & $-0.13^{n s}$ & $-0.17^{n s}$ & 1 & & & \\
\hline $\mathrm{C}_{\text {mic }}$ & $0.16^{\mathrm{ns}}$ & $-0.10^{\text {ns }}$ & $-0.04^{\mathrm{ns}}$ & $0.10^{\mathrm{ns}}$ & $0.20^{\mathrm{ns}}$ & $0.18^{\text {ns }}$ & $0.29^{*}$ & $0.17^{\mathrm{ns}}$ & $0.14^{\mathrm{ns}}$ & $0.08^{\text {ns }}$ & $0.17^{* *}$ & 1 & & \\
\hline $\mathrm{qCO}_{2}$ & $-0.09^{n s}$ & $0.15^{\mathrm{ns}}$ & $0.09^{\text {ns }}$ & $-0.09^{n s}$ & $-0.17^{n s}$ & $-0.22^{\mathrm{ns}}$ & $-0.20^{\mathrm{ns}}$ & $-0.13^{\mathrm{ns}}$ & $-0.05^{n s}$ & $-0.10^{\text {ns }}$ & $-0.01^{\mathrm{ns}}$ & $-0.71^{* *}$ & 1 & \\
\hline SOC & $0.44^{\mathrm{ns}}$ & $-0.11^{\mathrm{ns}}$ & $-0.33^{* *}$ & $0.55^{* *}$ & $0.40^{* *}$ & $0.45^{* *}$ & $0.56^{* *}$ & $0.53^{* *}$ & $0.52^{* *}$ & $0.42^{* *}$ & $0.24^{*}$ & $0.29^{* *}$ & $-0.22^{* *}$ & 1 \\
\hline
\end{tabular}

$\mathrm{pH}$ : potential of hydrogen; $\mathrm{Al}^{3+}$ : aluminum; $\mathrm{H}+\mathrm{Al}^{3+}$ : potential acidity; $\mathrm{K}^{+}$: potassium; $\mathrm{P}$ : phosphorus; $\mathrm{Ca}^{2+}$ : calcium; $\mathrm{Mg}^{2+}$ : magnesium; $\mathrm{SB}$ : sum of bases;

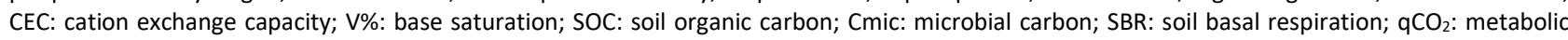
quotient; ns: not significant; ${ }^{*}$ and ${ }^{* *}$ : significant at $5 \%(p \leq 0.05)$ and $1 \%(p \leq 0.01)$ of probability, respectively.

The macronutrients presented a positive correlation with each other and with the SB, CEC, and V\%. The relationship between CEC and macronutrients is an important indicator of soil quality since it reflects the soil capacity in retaining essential cations to the plants, such as $\mathrm{K}^{+}, \mathrm{Ca}^{2+}$, and $\mathrm{Mg}^{2+}$, contributing to the increase of the SB and V\%. The positive correlation of the $\mathrm{C}_{\text {mic }}$ and $\mathrm{K}^{+}$with the SBR is related to greater carbon incorporation in the microorganisms due to high microbial activity, since, at respiration, the organisms consume carbon and release nutrients, such as $\mathrm{K}^{+}$, into the soil.

The negative correlation between $\mathrm{SOC}$ and $\mathrm{Al}^{3+}$ occurs due to the accumulation of organic matter in having the ability to complex $\mathrm{Al}^{3+}$ ions, reducing its toxicity and availability in the soil solution (BALDOTTO et al., 2015). Furthermore, the positive correlation with macronutrients, SB, V\%, CEC, SBR, and Cmic occurs because the SOC corresponds to approximately $58 \%$ of the soil organic matter, which features several functions, such as the generation of negative electric charges, nutrient availability, soil aggregation (NELSON et al., 1996), and the increase of the community of fungi, bacteria, and actinomycetes (WILLEKENS et al., 2014), characterizing the determination of the total organic carbon as an important indicator of soil quality.

The positive correlation between SOC and CEC demonstrates the relationship between these two attributes, that is, the CEC tends to be higher in places where the SOC contents are higher. Bottega et al. (2013), when studying the effects of the accumulation of organic matter on the cation exchange capacity of soils with low-reactivity clays, concluded that the accumulation of organic matter, 21 years after the adoption of the no-tillage system, promoted an expressive increase in the soil CEC, which is essential for this scenario where there is a predominance of materials with low activity in the clay fraction.

\section{CONCLUSIONS}

In general, our results showed that the use of no-tillage systems, besides keeping the soil covered, promotes increments in the biological and chemical attributes of the soil, improving soil quality, especially in already consolidated systems, as demonstrated by the carbon of the microbial biomass and by basal respiration, which are considered sensitive indicators of soil quality.

With the adoption of management systems that preconize minimum soil turning and the use of crop 
rotation, either at short or long adoption periods, it is possible to maintain the levels of soil organic carbon at contents close to those of areas with native vegetation, which shall influence in the improvement of some soil attributes and consequently its quality, considering that carbon presented a positive correlation with most of the studied variables.

The existing correlation between the chemical and biological attributes indicates that both factors work in a joint manner for the improvement of soil quality since an adequate nutrient distribution contributes positively to the biological attributes, just as the improvement of soil biology favors the chemical attributes. In view of this, this study demonstrates that soil management practices, with the introduction of plant residues, can be a promising option for a sustainable production system.

\section{REFERENCES}

ACQUA, N. H. D.; SILVA, G. P.; BENITES, V. M.; ASSIS, R. L.; SIMON, G. A.. Métodos de amostragem de solos em áreas sob plantio direto no Sudoeste Goiano. Revista Brasileira Engenharia Agrícola e Ambiental, v.17, p.117-122, 2013. DOI: http://dx.doi.org/10.1590/S1415-43662013000200001

ALVES, T. S.; CAMPOS, L. L.; NETO, N. E.; MATSUOKA, M.; LOUREIRO, M. F.. Biomassa e atividade microbiana de solo sob vegetação nativa e diferentes sistemas de manejos. Acta Science Agronomy, v.33, p.341-347, 2011. DOI: https://doi.org/10.4025/actasciagron.v33i2.4841

BABUJIA, L. C.; HUNGRIA, M.; FRANCHINI, J. C.; BROOKES, P. C.. Microbial biomass and activity at various soil depths in a Brazilian oxisol after two decades of no-tillage and conventional tillage. Soil Biology and Biochemistry v.42, p.2174-2181, 2010. DOI: https://doi.org/10.1016/j.soilbio.2010.08.013

BALDOTTO, M. A.; VIEIRA, E. M.; SOUZA, D. O.; BALDOTTO, L. E. B.. Estoque e frações de carbono orgânico e fertilidade de solo sob floresta, agricultura e pecuária. Revista Ceres, v.62, p.301-309, 2015. DOI: http://dx.doi.org/10.1590/0034737X201562030010

BUSTAMANTE, M. M. C.; MARTINELLI, L. A.; OMETTO, J. P. H. B.; CARMO, J. B.; JARAMILLOS, V.; GAVITOS, M.; ARAUJO, P.; AUSTIN, A. T. A.; PEREZ, T.; MARQUINA, S.. Innovations for a sustainable future: rising to the challenge of nitrogen greenhouse gas management in Latin America. Current Opinion in Environmental Sustainability, v.9, p.73-81, 2014. DOI: https://doi.org/10.1016/j.cosust.2014.09.002

CARNEIRO FILHO, A. C.; COSTA, K.. A Expansão da Soja no Cerrado. Caminhos para a ocupação territorial, uso do solo e produção sustentável. São Paulo: Agroicone, 2016.

CARVALHO, A. M.; COELHO, M. C.; DANTAS, R. A.; FONSECA, O. P.; GUIMARÃES JÚNIOR, R.; FIGUEIREDO, C. C.. Chemical composition of cover plants and its effect on maize yield in no-tillage systems in the Brazilian savana. Crop and Pasture Science, v.63, p.1075-1081, 2012. DOI: https://doi.org/10.1071/CP12272

COSTA, T. G. A.; IWATA, B. F.; SOUZA, W. S.; ROCHA, I. L.; SILVA, A. C. R.; MAIA, E. P. V.; FERREIRA, P. F. A.; NASCIMENTO, C. A. J.; ALVES, A. S.. Influence of management on maintenance and dynamics of carbon in the soil. Revista Ibero Americana de Ciências Ambientais, v.12, n.1, p.11-22, 2021. DOI: http://doi.org/10.6008/CBPC2179$\underline{6858.2021 .001 .0002}$

DIAS, F. P. M.; HÜBNER, R.; NUNES, F. J.; LEANDRO, W. M.; XAVIER, F. A. S.. Effects of land-use change on chemical attributes of a Ferralsol in Brazilian Cerrado. Catena, v.177, p.180-188, 2019. DOI: https://doi.org/10.1016/i.catena.2019.02.016

ENSINAS, S. C.; SERRA, A. P.; MARCHETTI, M. E.; SILVA, E. F.; PRADO, E. A. F.; LOURENTE, E. R. P.; ALTOMAR, P. H.; POTRICH, D. C.; MARTINEZ, M. A.; CONRAD, V. A.; JESUS, M. V. E.; KADRI, T. C.. Cover crops affect on soil organic matter fractions under no till system. Australian Journal Crop Science, v.10, p.503-512, 2016. DOI: http://doi.org/10.21475/ajcs.2016.10.04.p7247x

EZE, S.; PALMER, S. M.; CHAPMAN, P. J.. Soil organic carbon stock and fractional distribution in upland grasslands. Geoderma, v.314, p.175-183, 2018. DOI: https://doi.org/10.1016/j.geoderma.2017.11.017

FAGERIA, N. K.. Dry Matter Yield and Shoot Nutrient Concentrations of Upland Rice, Common Bean, Corn, and Soybean Grown in Rotation on an Oxisol. Communications in Soil Science and Plant Anal, v.35, p.961-974, 2004.

FRAZÃO, L. A.; PICCOLO, M. C.; FEIGL, B. J.; CERRI, C. C.; CERRI, C. E. P.. Inorganic nitrogen, microbial biomass and microbial activity of a Sandy Brazilian Cerrado soil under different land uses. Agriculture, Ecosystems \& Environment, v.135, p.161-167, 2010. DOI: https://doi.org/10.1016/j.agee.2009.09.003

GARCÍA-ORENES, F.; MORUGÁN-CORONADO, A.; ZORNOZA, R.; SCOW, K.. Changes in Soil Microbial Community Structure Influenced by Agricultural Management Practices in a Mediterranean Agro-Ecosystem. Plos One, v.11, p.1-9, 2013. DOI: https://doi.org/10.1371/journal.pone.0152958

ISLAM, K. R.; WEIL, R. R.. Microwave irradiation of soil for routine measurement of microbial biomass carbon. Biology Fertility Soils, v.27, p.408-416, 1998.

KUZYAKOV, Y.. Priming effects: Interactions between living 
and dead organic matter. Soil Biology Biochemistry, v.42, p.1363-1371, 2010. DOI: https://doi.org/10.1016/i.soilbio.2010.04.003

LAL, R.. Sequestering carbon in soils of agro-ecosystems. Food Policy, v.36, p.33-39, 2011. DOI:

https://doi.org/10.1016/j.foodpol.2010.12.001

LEITE, L. F. C.; GALVÃO, S. R. S.; HOLANDA NETO, M. R.; ARAÚJO, F. S.; IWATA, B. F.. Atributos químicos e estoques de carbono em Latossolo sob plantio direto no cerrado do Piauí. Revista Brasileira de Engenharia Agrícola e Ambiental, v.14, p.1273-1280, 2010.

MARSCHNER, H.. Mineral nutrition of higher plants. 2 ed. London, Academic Press., 1995.

MENDONÇA, V. Z.; MELLO, L. M. M.; ANDREOTTI, M.; PARIZ, C. M.; YANO, E. H.; PEREIRA, F. C. B. L.. Liberação de nutrientes da palhada de forrageiras consorciadas com milho e sucessão com soja. Revista Brasileira Ciência do Solo, v.39, p.183-193, 2015.

MERCANTE, F. M.; SILVA, R. F.; FRANCELINO, C. S. F.; CAVALHEIRO, J. C. T.; OTSUBO, A. A.. Microbial biomass, in a Red Argisol, in different vegetable coverings, in an area cultivated with cassava. Acta Science Agronomy, v.5, p.479485, 2008.

MOREIRA, A.; SFREDO, G. J.; MORAES, L. A. C.; FAGERIA, N. $\mathrm{K}$.. Lime and cattle manure in soil fertility and soybean grain yield cultivated in tropical soil. Communications in Soil Science and Plant Analysis, v.46, p.1157-1169, 2015. DOI: https://doi.org/10.1080/00103624.2015.1033542

MUNIZ, L. C.; MADARI, B. E.; TROVO, J. B. F.; CANTANHÊDE, I. S. L.; MACHADO, P. L. O. A.; COBUCCI, T.; FRANÇA, A. F. S.. Soil biological attributes in pastures of different ages in a crop livestock integrated system, Brazil. African Journal of Agricultural Research, v.13, p.77-81, 2011.

OLIVEIRA, W. R. D.; RAMOS, M. L. G.; CARVALHO, A. M.; COSER, T. R.; SILVA, A. M. M.; LACERDA, M. M.; SOUZA, K. W.; MARCHÃO, R. L.; VILELA, L.; PULROLNIK, K.. Dynamics of soil microbiological attributes under integrated production systems, continuous pasture, and native Cerrado. Pesquisa Agropecuária Brasileira, v.51, p.1501-1510, 2016.

PARIZ, C. M.; ANDREOTTI, M.; BUZETTI, S.; BERGAMASCHINE, A. F.; ULIAN, N. A.; FURLAN, L. C.; MEIRELLES, P. R. L.; CAVASANO, F. A.. Straw decomposition of nitrogen-fertilized grasses intercropped with irrigated maize in an integrated crop-livestock system. Revista Brasileira de Ciência do Solo, v.35, p.2029-2037, 2011.

PARKIN, T. B.; DORAN, J. W.; FRANCOP-VIZCAÍNO, E.. Field and laboratory tests of soil respiration. In: DORAN, J. W.; JONES, A. J.. Methods for assessing soil quality. Madison: Soil Science Society of America, 1996. p.231-245.

RAZA, M. A.; KHALID, M. H. B.; ZHANG, X.; FENG, L. Y.; KHAN, I.; HASSAN, M. J.; AHMED, M. M.; ANSAR, M.; CHEN, Y. K.; FAN, Y. F.; YANG, F.. Effect of planting patterns on yield, nutrient accumulation and distribution in maize and soybean under relay intercropping systems. Scientific Reports, v.9, p.1-14, 2019. DOI: https://doi.org/10.1038/s41598-019$\underline{41364-1}$
SANTANA, A. S.; CHAVES, J. S.; SANTANA, A. S.; RODRÍGUEZ, C. A.; MORAES, E. R.. Biomassa microbiana em diferentes sistemas de manejo do solo no sul do estado de Roraima. Revista Brasileira de Ciências da Amazônia, v.6, p.43-50, 2017.

SANTOS, C. A.; REZENDE, C. P.; PINHEIRO, E. F. M.; PEREIRA, J. M.; ALVES, B. J. R.; URQUIAGA, S.; BODDEY, R. M.. Changes in soil carbon stocks after land-use change from native vegetation to pastures in the Atlantic forest region of Brazil. Geoderma, v.337, p.394-401, 2019. DOI: https://doi.org/10.1016/i.geoderma.2018.09.045

SANTOS, H. G.; JACOMINE, P. K. T.; ANJOS, L. H. C.; OLIVEIRA, V. A.; LUMBRERAS, J. F.; COELHO, M. R.; ALMEIDA, J. A.; ARAUJO FILHO, J. C.; OLIVEIRA, J. B.; CUNHA, T. J. F.. Sistema brasileiro de classificação de solos. 5 ed. Brasília: Embrapa, 2018.

SHIWAKOTI, S.; ZHELJAZKOV, V. D.; GOLLANY, H. T.; KLEBER, M.; XING, B.. Effect of tillage on macronutrients in soil and wheat of a long-term dryland wheat-pea rotation. Soil and Tillage Research, v.190, p.194-201, 2019. DOI: https://doi.org/10.1016/j.still.2019.02.004

SILVA, M. B.; KLIEMANN, H. J.; SILVEIRA, P. M. D.; LANNA, A. C.. Atributos biológicos do solo sob influência da cobertura vegetal e do sistema de manejo. Pesquisa Agropecuária Brasileira, v.42, p.1755-1761, 2007. DOI: http://doi.org/10.1590/S0100-204X2007001200013

SOARES, D. S.; RAMOS, M. L. G.; MARCHÃO, R. L.; MACIEL, G. A.; OLIVEIRA, A. D.; MALAQUIAS, J. V.; CARVALHO, A. M.. How diversity of crop residues in long-term no-tillage systems affect chemical and microbiological soil properties. Soil and Tillage Research, v.194, p.104316, 2019. DOI: https://doi.org/10.1016/i.still.2019.104316

TANG, H.; LI, C.; XIAO, X.; TANG, W.; CHENG, K.; PAN, X.; WANG, K.; LI, W.. Soil physical and chemical quality as influenced by soil tillage managements under double cropping rice system of southern China. Acta Agriculturae Scandinavica, v.70, p.14-23, 2020. DOI: https://doi.org/10.1080/09064710.2019.1662082

TEXEIRA, P. C.; DONAGEMA, G. K.; FONTANA, A.; TEIXEIRA, W. G.. Manual de métodos de análise de solos. 3 ed. Brasília: Embrapa, 2017.

UN. United Nations. World Population Prospects 2019: Highlights. Department of Economic and Social Affairs, Population Division, 2019.

VICENTE, L. C.; GAMA-RODRIGUES, E. F.; GAMA-RODRIGUES, A. C.. Organic carbon within soil aggregates under forestry systems and pasture in a southeast region of Brazil. Catena, v.182, p.104-139, 2019. DOI:

https://doi.org/10.1016/j.catena.2019.104139

WALKLEY, A.; BLACK, I. A.. An examination of Degtjareff method for determining soil organic matter, and proposed modification of the chromic acid tritation method. Soil Science, v.37, p.29-38, 1934.

YEOMANS, J. C.; BREMNER, J. M.. A rapid and precise method for routine determination of organic carbon in soil. 
Communications in Soil Science and Plant Analysis, v.19,

p.1467-1476, 1988

A CBPC - Companhia Brasileira de Produção Científica (CNPJ: 11.221.422/0001-03) detém os direitos materiais desta publicação. Os direitos referem-se à publicação do trabalho em qualquer parte do mundo, incluindo os direitos às renovaç̃oses, expansões e disseminações da contribuição, bem como outros direitos subsidiários. Todos os trabalhos publicados eletronicamente poderão posteriormente ser publicados em coletâneas impressas sob coordenação da Sustenere Publishing, da Companhia Brasileira de Produção Científica e seus parceiros autorizados. Os (as) autores (as) preservam os direitos autorais, mas não têm permissão para a publicação da contribuição em outro meio, impresso ou digital, em português ou em tradução. 